\title{
Agronomic Potential of Two Legumes in the Sandy Soils Fertility Restoration Process in the South-West of Côte d'Ivoire
}

\section{Germaine A. Tanoh,}

Department of Soil Science, Research and Training Unit, Earth Sciences and Mining Resources (ESMR or STRM), University Felix Houphouët Boigny of Cocody, Abidjan, Côte d'Ivoire

Jean Baptiste D. Ettien,

Department of Soil Science, Research and Training Unit, Earth Sciences and Mining Resources (ESMR or STRM), University Felix Houphouët Boigny of Cocody,Abidjan, Côte d'Ivoire

Centre Suisse de Recherches Scientifiques en Côte d'Ivoire, Department of Food Security and Nutrition

\section{Félix B.O. Bouadou,}

Department of Soil Science, Research and Training Unit, Earth Sciences and Mining Resources (ESMR or STRM), University Felix Houphouët Boigny of Cocody, Abidjan, Côte d'Ivoire

Doi:10.19044/esj.2020.v16n27p133 URL:http://dx.doi.org/10.19044/esj.2020.v16n27p133

\begin{abstract}
A study on the agronomic potential of two legumes, Acacia mangium and peanut, was conducted in the town of Grand-Lahou in the South-West of Côte d'Ivoire. This paper focuses on assessing the capacity of the two legumes to provide organic matter to the poor soil in a bid to restore it for yam cultivation. The apparatus in complete randomized blocks comprising 4 treatments was installed from 2017 to 2019 on a sandy soil with 5\% slope. This include the peanut treatment intake T1 (20,000 feet/ha), Acacia mangium intake T2 (834 feet/ha), peanut + Acacia mangium intake T3, and the apparatus without fertilizer intake $\mathrm{T} 0$. The soil responsiveness, the biomass characterization, and the nodules enumeration are the different agronomic parameters collected periodically in the test. The low $\mathrm{pH}$ obtained under pure peanut $(\mathrm{pH}=4.44)$ and under pure Acacia mangium $(\mathrm{pH}=4.09)$ indicated that the soils under the two treatments are strongly acidic $(\mathrm{pH}<5,5)$. The plot consisting entirely of peanut produced a significant leaf biomass estimated at 94,656 leaves compared to that produced by peanut associated with Acacia mangium (66,960 leaves) in six months. The weight of the litter under T2 (between $0.85 \mathrm{t} / \mathrm{ha}$.year-1 and $1.13 \mathrm{t} / \mathrm{ha}$.year-1) was on average higher than the
\end{abstract}


weight of the litter of the T3 treatment (between $0.7 \mathrm{t} /$ ha.year- 1 and 0.49 $\mathrm{t} /$ ha.year-1) during the two sampling periods (6 months and 12 months). The chemical characterization of the Acacia mangium litter is rich in calcium $(73 \%)$ and is progressively less concentrated in magnesium (14\%), potassium (10\%), and sodium (2\%). The long monitoring of Acacia mangium biomass production could reveal significant levels of total bases for the soils in order to improve their physical and chemical fertility.

Keywords: Acacia Mangium, Peanut, Biomass, Fertility, Sandy Soils, Côte d'Ivoire

\section{Introduction}

Traditional agricultural production systems have ensured food selfsufficiency by managing soil fertility. This management is still based on the practice of fallow, which remains the main natural mechanism for restoring soil fertility through the accumulation of organic matter and the upturn in the shallow horizons of leached elements under crops (Roose, 2015; Ettien et al., 2016). Thus, this crop-fallow changeover was well suited to the low pressure of the population and the high land availability (Georges, 2015). Today, the strong pressure exerted on the lands, due to the population explosion, has resulted in the shortening of the duration of the fallows (Todan et al., 2017). This short fallow period is not sufficient for a sustainable soil fertility restoration. This factor has a negative impact on agricultural productivity as these soils are regularly used without rest and have poor organic matter. This means the loss of soil nutrients $(\mathrm{N}, \mathrm{P}, \mathrm{K}, \mathrm{Ca}, \mathrm{Mg})$ and the degradation of the soil organic carbon (SOC). In the absence of fertilization, yields are low, particularly for plants such as yam with a yield of around 6 to 10 t/ha (Ettien et al., 2013). Grand-Lahou is a very good example. Indeed, in the locality, cash crops such as cocoa, coffee, palm, and rubber represent the main crops. They occupy more than $80 \%$ of arable land at the expense of food crops supposed to ensure food security. To deal with these numerous agricultural constraints, alternative solutions of an agroecological nature exist in order to restore the fertility of marginal lands in the long term to increase crop yields. Legumes such as peanut and Acacia mangium could therefore be used as sustainable solutions to be integrated into the cropping system to raise soil SOC levels. Schneider and Huyghe (2015) demonstrated that the soil containing the peanut is an alternative to improve nitrogen nutrition. In Togo, the fertilizer trees-crops association has produced domestic wood over a long term, and it has restored, maintained the fertility of degraded lands over large areas, and substantially increased agricultural yield by up to $30 \%$ (Ndiaye, 2015). In Congo, the study of Kindiela et al. (2019) showed that Acacia mangium has allowed the restoration of the fertility of degraded soils and 
improved cassava yields. In Côte d'Ivoire Mid-west, yam yields were higher with Acacia mangium fallows on ferralitic soils than natural fallow. However, these fallows with tree legumes require more time to significantly improve soil fertility (Gnahoua et al., 2008). Today, it is therefore well known that legumes have high potential for nitrogen and SOC production in the process of restoring the soil nutrients pool. However, a beneficial legume-crop association should be applied so as to avoid competition between the legume and the crop. In this study, the association Acacia Mangium-Arachis hypogaea was adopted to restore and maintain the mineral elements of the sandy soil of Grand-Lahou, especially as an ecological alternative solution which is accessible to producers. This study thus aimed at assessing the soil fertility restoration potential of shrubby legume (Acacia Mangium) and dietary (Arachis hypogaea) in association with yams.

\section{Material And Methods}

\section{Experimental Site Description}

The study was carried out in N'gorankro 1(latitude $5^{\circ} 19^{\prime} 59^{\prime}$ 'N, longitude $5^{\circ} 1$ ' $39^{\prime \prime} \mathrm{W}$ ) located $10 \mathrm{~km}$ North of the town of Grand-Lahou (Figure. 1). The climate is of a humid equatorial type with an average rainfall of $2254 \mathrm{~mm}$ per year (Abé, 2005). Relative humidity ranges from 6.5 to $9.9 \%$.

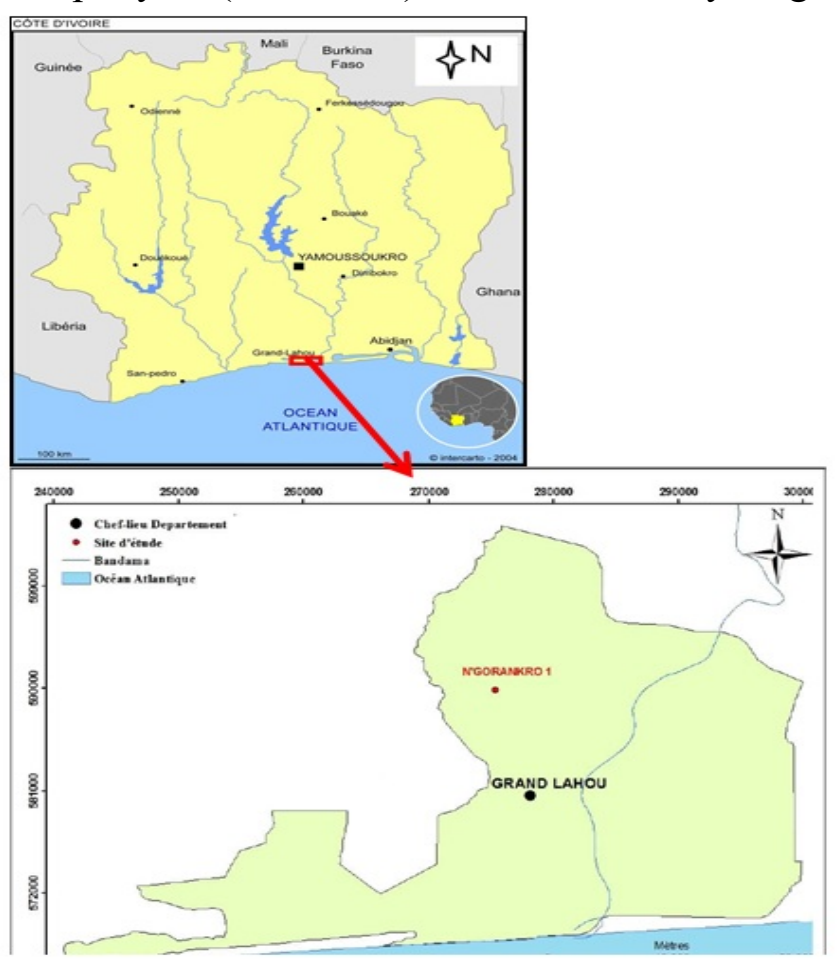

Figure 1. Localisation of the study area 


\section{Plant Material}

The plant material consisted of Acacia mangium seeds supplied by a national research institute and of Arachis hypogaea seeds obtained from producers (Figure 2).

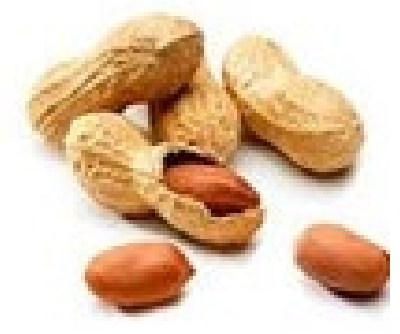

Arachis hypogaea

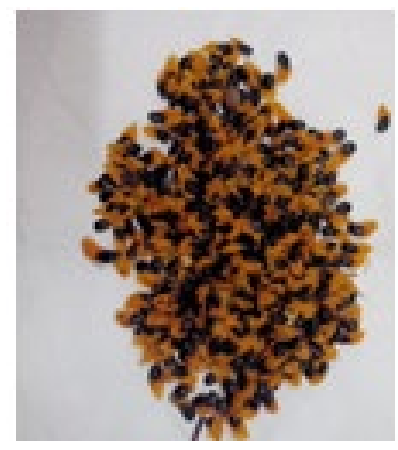

Acacia mangium

Figure 2. Arachis hypogaea and Acacia mangium seeds

\section{Soil Preparation}

The experimental plot was set up on a low-sloping land (5\%). After a surface manual plowing, the experimental apparatus was installed after picketing which is followed by direct sowing of the peanut. Acacia mangium was transplanted into holes after a 3-month nursery phase. No chemical fertilizer was added. Two peanut cycles were carried out per year in 2017 and 2018.

\section{Experimental Design}

The experimental apparatus used for the cultivation was the completely randomized block device (Figure 3).

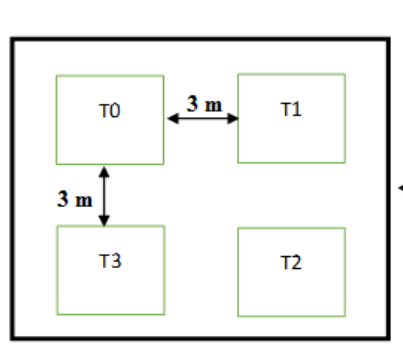

Block 1

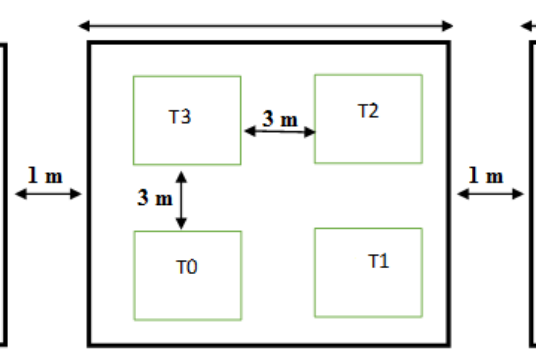

Block 2

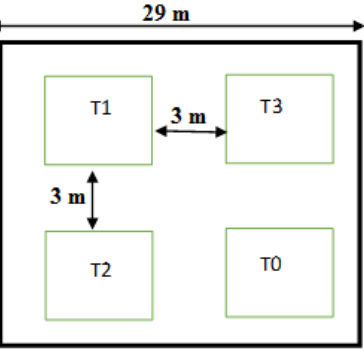

Block 3

T0: control (without legume), T1: pure peanut, T2: pure Acacia mangium, T3: A. mangium-Peanut

Figure 3. Completely randomized block experiment

The experimental plot was a site of $3600 \mathrm{~m}^{2}(60 \times 60)$ which is subdivided into three (3) repetitions. Each repetition was composed of 4 micro-plots 
whose dimensions were $144 \mathrm{~m}^{2}(12 \times 12)$. Thus, the test comprises of four treatments:

- T0 treatment: plot without legumes (control);

- T1 treatment: cultivation of pure peanut sown at 20,000 plants/ha;

- T2 treatment: pure Acacia mangium with a planting density of 834 feet per hectare;

- T3 treatment: Peanut + Acacia mangium.

\section{Soils Fertility Parameters Measurement}

The soil fertility parameters measured were the enumeration of nodules on the roots of Acacia mangium and Arachis hypogea as well as the biomass characterization (Acacia mangium and Arachis hypogea) as a source of organic matter production. The $\mathrm{pH}$ was determined to know the soil reactivity and the possible availability of nutrients in the soil. By means of an Edelman auger, soil samples were taken under Acacia mangium, in the root zone, after the peanut harvest and in the control. The collected soil was stored in storage bags and then sent to the laboratory to determine the $\mathrm{pH}$ and the chemical elements. The $\mathrm{pH}$ was measured with a $\mathrm{pH}$ meter (potentiometer) in the laboratory. Two types of $\mathrm{pH}$ determined are water $\mathrm{pH}$ (current acidity) and $\mathrm{KCl} \mathrm{pH}$ (total or potential acidity).

The biomass measurements and the nodules enumeration with the peanut were made on a line of length $1 \mathrm{~m}$ and width $0.2 \mathrm{~m}$. This is an area of $0.2 \mathrm{~m}^{2}$ which comprises of 10 peanut plants, avoiding border plants. The spacing between the peanut plants was $20 \mathrm{~cm}$ x $20 \mathrm{~cm}$ on the line and between the lines. The entire line per treatment in the apparatus included 120 peanut plants. Two lines of peanut were sown between two strips per elementary plot (treatment). This peanut seeding density was also applied for each treatment (T1 and T3) on the three repetitions (blocks). After the harvest, the total biomass (roots and leaves) recovered over $1 \mathrm{~m}$ (10 feet of peanut) was weighed using an electronic balance to obtain the fresh weight $(\mathrm{Fw})$ and then dried in an oven at $65{ }^{\circ} \mathrm{C}$ for 48 hours. After drying, the samples were reweighed to determine the dry weights $(\mathrm{Dw})$. Hence, the moisture content was determined by the following equation:

Where:

$$
\mathbf{H}(\%)=((\text { Fw - Dw }) / \text { Fw }) \times 100 .
$$

$$
\begin{aligned}
& \mathbf{H}=\text { Moisture content } \\
& \mathbf{F w}=\text { Fresh weight } \\
& \text { Dw }=\text { Dry weight }
\end{aligned}
$$

The remaining part of the biomass was spread between the yam strips of the treatment. For Acacia mangium plants, the nodules enumeration involves digging under the foot of the acacia plant in the root zone in view of observing and counting the nodules on all the roots. The biomass was obtained by collecting all the dry leaves that fell in the $1 \mathrm{~m}^{2}$ trays mounted on 4 stakes, and 
it was kept about $10 \mathrm{~cm}$ from the ground under Acacia mangium. These leaves were sent to the laboratory for chemical analysis.

\section{Results}

\section{Water-pH and $\mathrm{KCL}-\mathrm{pH}$}

The water-pH and $\mathrm{KCl}-\mathrm{pH}$ analysis results are given in Table 1 . The water-pH obtained under $\mathrm{T} 0$ shows that the soil is acidic $(\mathrm{pH}<6)$. The soils of the studied plots showed that peanut and Acacia mangium had no significant effect $(\mathrm{p}>0.05)$ on the evolution of the $\mathrm{pH}$ compared to the T0 control. The low water-pH obtained under pure peanut (water-pH $=4.44$ ) and under pure Acacia mangium (water-pH = 4.09) reflect that the soils under the two treatments are strongly acidic $(\mathrm{pH}<7)$. However, under the peanut associated with Acacia mangium, the water-pH obtained is 4.6. The KCL-pH values obtained are lower than those of the water-pH. Therefore, this reveals that the soils remain strongly acidic despite the treatments carried out. The values of $\Delta \mathrm{pH}$ (water-pH - KCL-pH) are all less than 1.

Table 1. One-way analysis of variance of $\mathrm{pH}$ variations in accordance with treatments under Acacia mangium and peanuts

\begin{tabular}{|c|c|c|c|}
\hline Treatments & Water pH & $\mathrm{KCl} p H$ & Water $p H-K C l p H$ \\
\hline TO & $4,63 a$ & $3,84 a$ & 0,79 \\
\hline$T 1$ & $4,44 a$ & $3,67 a$ & 0,77 \\
\hline$T 2$ & $4,09 a$ & $3,40 a$ & 0,69 \\
\hline T3 AM & $5,00 a$ & $4,25 a$ & 0,75 \\
\hline$T 3 A R$ & $4,20 a$ & $3,44 a$ & 0,71 \\
\hline $\boldsymbol{F}$ & 0,8992 & 0,8139 & \\
\hline $\operatorname{Pr}>F$ & $0,4998^{n s}$ & $0,5444^{n s}$ & \\
\hline
\end{tabular}

F: Fisher value; P: Probability. The affected averages of the same letter in the same column are not significantly different at the threshold $\alpha<0.05$. According to the Student method -

Newman - Keuls (SNK) ns = not significant

\section{Peanut Leaves Number Produced}

The results obtained after the leaves enumeration is shown in Table 2 . Observations made on the plot showed that there was no significant effect $(\mathrm{p}>$ 0.05 ) between the number of leaves produced by the peanut in pure cultivation and the peanut in associated cultivation. Nevertheless, it was noted that the plot consisting entirely of peanut produced a significant leaf biomass $(94,656$ leaves) compared to that produced by the peanut associated with Acacia mangium (66,960 leaves).

Table 2. Peanut leaves number on each treatment

\begin{tabular}{cc}
\hline Treatments & Peanut Leaves Number \\
\hline T1 & $94656 \mathrm{a}$ \\
T3 & $66960 \mathrm{a}$ \\
K (Observed Value) & 0,4286 \\
calculated P & $0,5127^{n s}$ \\
Theoretical P & 0,05 \\
\hline
\end{tabular}


The quantities of litter produced by Acacia mangium in T2 and T3 treatments, according to the sampling periods, are presented in Table 3. In general, the weight of the litter under T2 was on average systematically higher than the weight of the litter of the T3 treatment during the two sampling periods. This is without this difference being significant at the $5 \%$ threshold $(\mathrm{Pr}>\mathrm{F}=0.27)$. The different litter drop rates can be seen in Figure 4. The litter drop rate was generally higher under T2 (55-70\%) than under T3 (45-30\%) during the two samplings. The average litter production per Acacia mangium of 12-monthold is $0.8 \mathrm{t} /$ ha.year $^{-1}$. The distribution of the litter weights was generally symmetrical under the $\mathrm{T} 3$ treatment while that of $\mathrm{T} 2$ shows a greater spread in the high values (Figure 5).

Table 3. Produced litter quantity per Acacia mangium according to treatments and sampling periods (t/ha.year $\left.{ }^{-1}\right)$.

\begin{tabular}{ccc}
\hline Period & Treatments & Litter Quantity \\
\hline 6 months & T2 & $0,85 \mathrm{a}$ \\
& & \\
& $\mathrm{T} 3$ & $0,7 \mathrm{a}$ \\
\multirow{2}{*}{12 months } & $\mathrm{T} 2$ & $1,13 \mathrm{a}$ \\
& $\mathrm{T} 3$ & $0,49 \mathrm{a}$ \\
& $\mathrm{CV}(\%)$ & 88,420 \\
& $\mathrm{Pr}>\mathrm{F}$ & 0,27 \\
& $\mathrm{ppds} 0.5$ & 0,67 \\
\hline
\end{tabular}

Averages with the same letter are not significantly different, according to the Fisher Test (LSD).

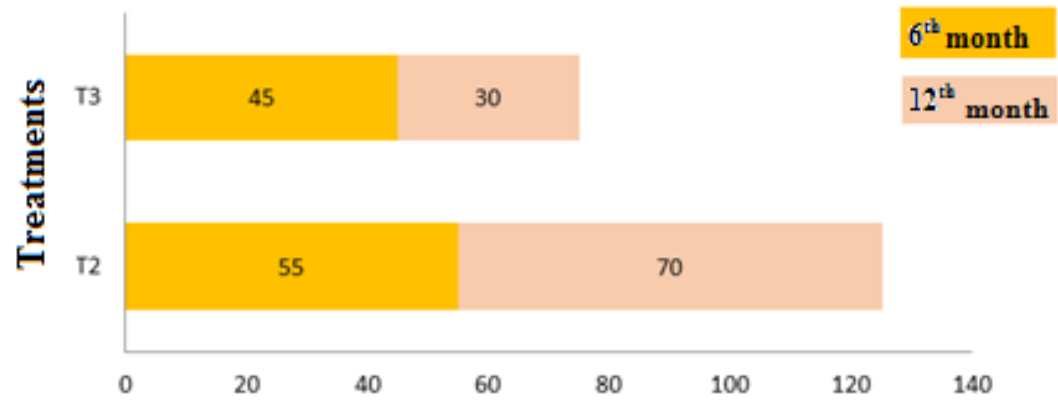

Fall rate

Figure 43. Dead Leaves Falling Rate (litter). 


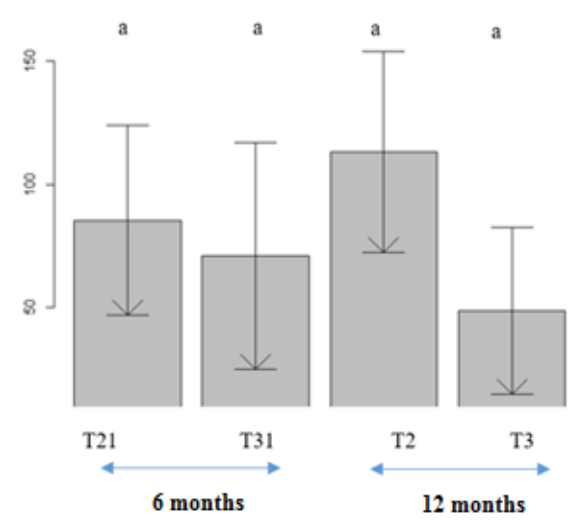

Figure 5. Average litter weight scores (t/ha) by treatment group and $95 \%$ confidence intervals.

The mustache box (Figure 6) allows us to visualize the extreme quantities (outliers) of litter under the two treatments. The histogram shows the frequencies of the classes of these weights (scores) by treatment group (Figure 7). The frequency of the small quantities of litter taken is higher between 0 and 50 than that of the largest quantities of litter produced during the duration of the study (12 months). This shows a slight leaf fall of $A$. mangium at 12 months of age in this study.

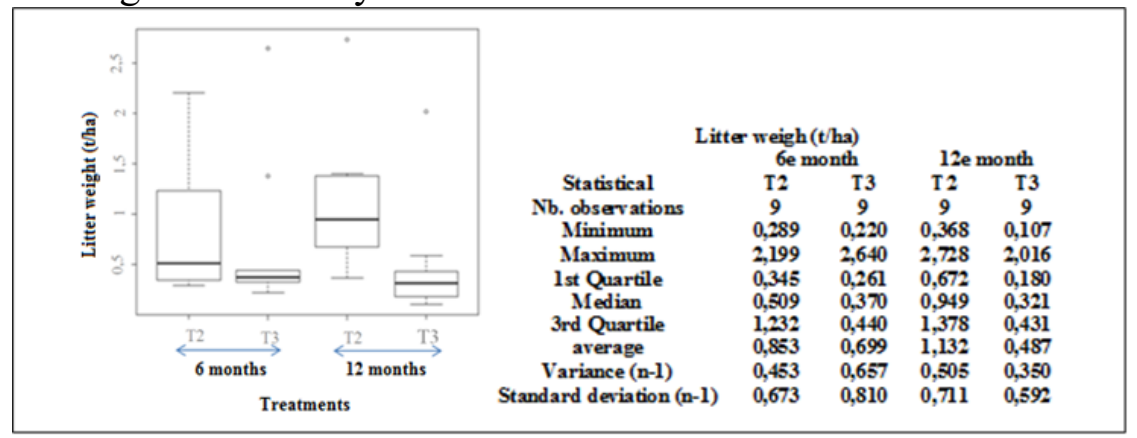

Figure 64. Mustache boxes of litter weight scores by treatment group

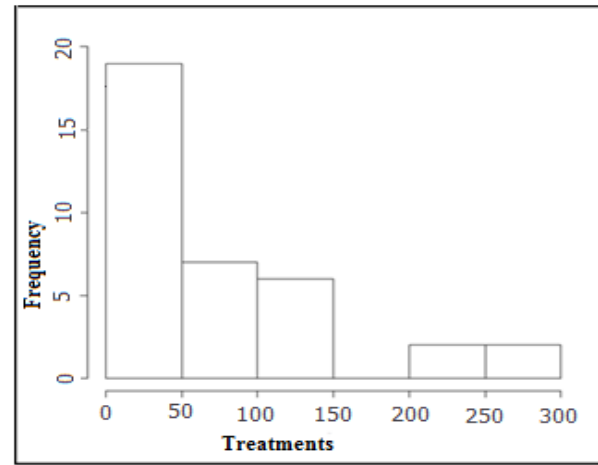

Figure 7. Histogram of litter weight scores per group of treatments 


\section{Chemical Characteristics of the Acacia mangium Litter}

The results of Acacia mangium litters chemical analysis are shown in Table 4. The elements measured out were calcium (Ca), magnesium $(\mathrm{Mg})$, potassium $(\mathrm{K})$, and sodium $(\mathrm{Na})$. These results were compared to the soil fertility thresholds, particularly sandy soils. Furthermore, these fertilizers from the 12-month-old Acacia mangium litter have very low content (Table 4). The average mass concentrations obtained in $\mathrm{Ca}, \mathrm{Mg}, \mathrm{K}$ and $\mathrm{Na}$ are $9.21 \mathrm{~kg} / \mathrm{ha}$, $1.79 \mathrm{~kg} / \mathrm{ha}, 1.28 \mathrm{~kg} / \mathrm{ha}$ and $0.28 \mathrm{~kg} / \mathrm{ha}$, respectively. The pie chart (Figure 8) makes it possible to distinguish the proportion of each of these elements measured out. Thus, the litter of Acacia mangium had a higher percentage of calcium $(73 \%)$ than magnesium (14\%), potassium $(10 \%)$, and sodium $(2 \%)$.

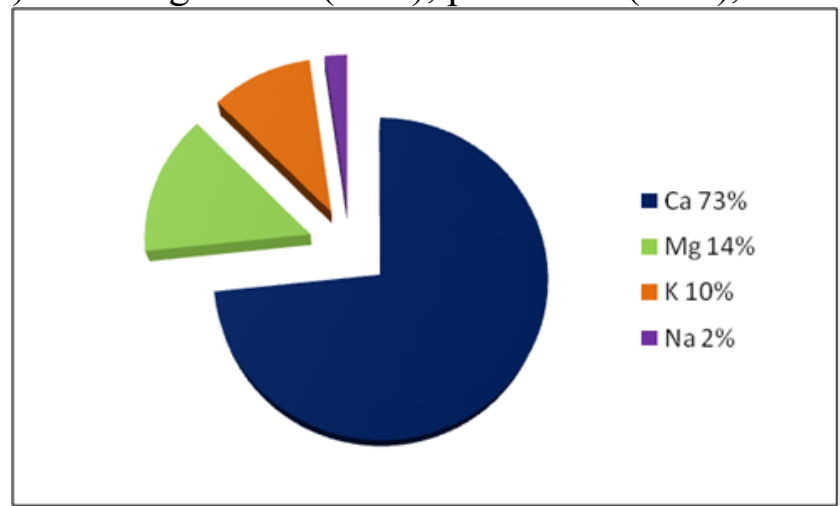

Figure 85. Pie chart of the mineral elements of A. mangium litter

Table 4. Mass concentration of the fertilizing elements of Acacia mangium litter ( $\mathrm{kg} / \mathrm{ha})$

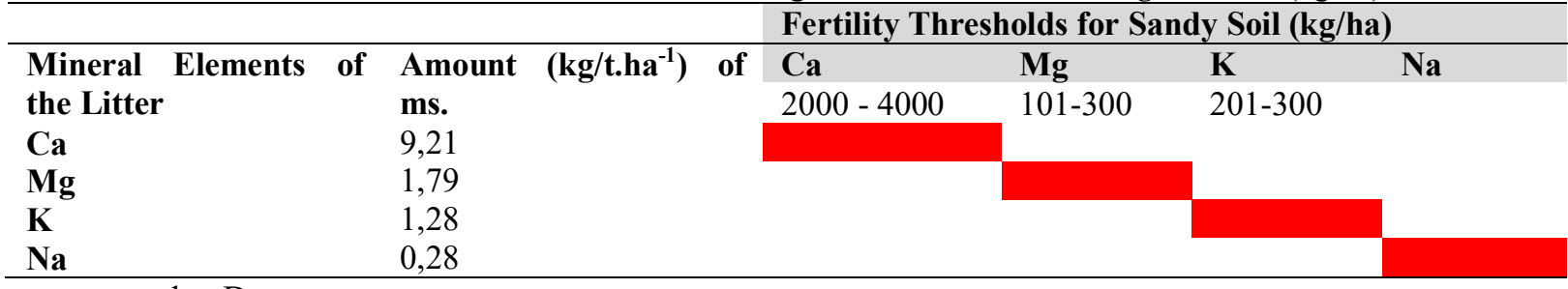

dm. Dry matter

- K: Reference guide to fertilization, 1st ed. (Craaq, 2003) cited in the Guide to the overall management of diversified organic vegetable gardening (Équiterre, 2011 in Cégep de Victoriaville et Ghislain Jutras)

- Ca: Guide to global management of diversified organic market gardening (Équiterre, 2011 in Cégep de Victoriaville et Ghislain Jutras)

- Mg: Craaq (2003, p. 280) and Guide to global management of diversified organic vegetable gardening (Équiterre, 2011 in Cégep de Victoriaville et Ghislain Jutras). 


\section{Nodules Number Produced}

Table 5 summarizes the results obtained after counting the nodules on 10 feet of peanut $\left(0.2 \mathrm{~m}^{2}\right)$ on the 80 th day. Therefore, these results show a high number of nodules in the peanut in pure cultivation $(73,174$ nodules) and the small quantity was obtained with the peanut in the cultivation associated with the acacia mangium (T3) (50,640s nodules). However, this difference was not significant $(\mathrm{p}>0.05)$ for the two treatments.

Table 5. Nodules number on the peanut

\begin{tabular}{cc}
\hline Treatments & Nodules number \\
\hline T3 & $1820,00^{\mathrm{a}}$ \\
$\mathrm{T} 1$ & $2576,67^{\mathrm{a}}$ \\
$\mathrm{Pr}>\mathrm{F}$ & 0,7709 \\
\hline
\end{tabular}

With Acacia mangium, no nodule has been counted from 6 months and on all acacia feet.

\section{Discussion}

\section{pH as Good Indicator of Soil Fertility and its Restoration Process}

Consequently, the objectives of this study were to find out the potential for organic matter input by two legumes in order to increase the agricultural crops yields on marginal soils in the town of Grand-Lahou. These marginal soils of the site were essentially sandy with a content of more than $85 \%$ sand. This feature of the soils indicates a low capacity of water retention highlighted by the plot having no contribution of legumes (T0). According to Bonneau and Souchier (1979), knowledge of the useful reserve (UR) of a soil for agricultural use is very important. Indeed, the contribution of this UR is a good indicator of the richness of the soil solution in nutrients for the plants mineral and water nutrition. As for the $\mathrm{pH}$, the results obtained after the soils analysis gave low water-pH values. The water-pH of the control treatment (water-pH $=4.63$ ) indicates that the soils of the study site are acidic. The water-pH of the soils under treatment is changing. Soils under pure $A$. mangium and peanut are very acidic ( $\mathrm{pH}$-water $<4.5)$ unlike acidic soils standards $(4.5<\mathrm{pH}$-water $<5.5)$ under Acacia magium-peanut. Indeed, soils are generally acidic with water$\mathrm{pH}-\mathrm{KCL}-\mathrm{pH}$ values lower than 1 . Thus, this acidity is due to acidifying ions such as $\mathrm{Al}^{3+}, \mathrm{Fe}^{2+}, \mathrm{Fe}^{3+}$ and $\mathrm{Mn}^{2+}$ which, in addition to the acidifying character, can cause toxicity phenomena (aluminous, ferrous or magnesium toxicity) when they are above the required thresholds.

\section{Biomasses Produced by the Two Legumes of Soil Fertility}

In terms of biomass, the cultivation of pure peanut (T1) produced 94,656 leaves, unlike the T3 treatment in cultivation combined with $A$. mangium (66,960 leaves). This difference is related to the plantation density which is only three rows of $A$. mangium. The dry weight of the total biomass 
varies from $171.52 \mathrm{~kg} /$ ha for the peanut alone and from $168.88 \mathrm{~kg} / \mathrm{ha}$ for the associated crop. The obtained biomass after the harvest of the first cycle of peanut was left on site and used as straw. Hence, this made it possible to protect the soil against erosion and provide organic matter to the soil, thus ensuring the maintenance of the physicochemical and biological fertility of the soils for the second cycle. This mass left on the soil provides litter and enriches the soil with nitrogen as demonstrated by Bado (2002). Here, the peanut biomass was used as green fertilizer by landfill. These leaves play an important role in catching the atmospheric nitrogen and is used in the production of organic matter (Gnahoua et al., 2016; Ettien et al., 2016).

However, the biomass produced in the A.mangium in one year (6th and 12 th month) showed a slight variation between the quantities of litter $(0.85$ $\mathrm{t} /$ ha for T2 and $0.7 \mathrm{t} /$ ha for T3 at 6 months; $1.13 \mathrm{t} /$ ha for T2 and $0.49 \mathrm{t} /$ ha for $\mathrm{T} 3$ at 12 months). From a statistical standpoint, the biomass produced in treatments 2 and 3 are identical. This reveals that whatever the treatment (pure Acacia mangium or Acacia mangium associated with peanut), the biomass production remains the same. Furthermore, the results show that the sampling period (at 6 months and 12 months) had no significant effect on the quantity of litter produced. Also, the production rate was generally higher under T2 than under T3, unlike the production of leaves which presented the opposite. In T3 treatment, the combination of Acacia mangium and peanut had a mutually positive effect and helped maintain soil humidity. This condition made it possible to limit the evapotranspiration under T3 and therefore the wilting depreciation of the leaves of Acacia mangium in this treatment. Thus, the study found that at the age of 12 months, Acacia mangium is capable of producing an average of $0.8 \mathrm{t} / \mathrm{ha}$ of litter. This quantity, compared to previous works, is close to that of certain authors Krisnawati et al. (2011). They have shown in a study on the performances of Acacia mangium that in one (1) year, it produces 1.7 to $3.64 \mathrm{t} /$ ha.year. Still, it is less significant compared to other works carried out on older population. For example, the study of Gnahoua et al. (2008) showed that the 5.5-year-old Acacaia mangium could produce 7.8 $\mathrm{t} /$ ha.year $^{-1}$. This difference in the quantity of litter produced is therefore attributable to the age of the population (Bernhard-Reversat \& Schwartz, 1997). Consequently, after 4 years, the quantity of litter on our experimental site may eventually reach 7 to $10 \mathrm{t} /$ ha. ear $^{-1}$. Nonetheless, the litter produced in this study is an important source of organic matter to considerably restore the physical, chemical, and biological properties of the sandy soils of GrandLahou. According to Moreau (1993) and Gnahoua (2003), the decomposition of these litters improves the physicochemical properties of the soil, the water retention capacity, the cationic exchange capacity (CEC) as well as the organic activity. Moreover, this litter fallout is a source of potentially mineralizable organic matter (N'goran, 2008; Gnahoua et al., 2008), which can therefore 
provide important nutrients to the soil, including carbon $(\mathrm{C})$, phosphorus $(\mathrm{P})$ and nitrogen $(\mathrm{N})$, basic components of living tissues as well as exchangeable cations such as $\mathrm{Ca}^{2+}, \mathrm{Mg}^{2+}, \mathrm{K}^{+}$, and $\mathrm{Na}^{+}$. This organic matter participates in the maintenance of the soil structure by allowing its cohesion and improving the penetration of water in depth (Razafindramanana et al., 2012). In the long term, Acacia mangium could significantly correct the acidity state $(\mathrm{pH} 3.90$ to 5.5) of the soils of Grand-Lahou and restore the fertility of these soils by adding large quantities of litter.

\section{Chemical Potential of the Litter Produced for Soil Fertility Restoration Process}

The chemical analysis of the 12-month-old Acacia mangium litter gave extremely low levels of calcium $(\mathrm{Ca})$, magnesium $(\mathrm{Mg})$, potassium $(\mathrm{K})$ and sodium (Na), compared with soil fertility thresholds (Craaq, 2003). The different respective mass concentrations obtained are: $\mathrm{Ca}\left(9,208 \mathrm{~kg} \cdot \mathrm{ha}^{-1}\right), \mathrm{Na}$ $\left(0,28 \mathrm{~kg} \cdot \mathrm{ha}^{-1}\right), \mathrm{Mg}\left(1.792 \mathrm{~kg} \cdot \mathrm{ha}^{-1}\right)$, and $\mathrm{K}\left(1,28 \mathrm{~kg} \cdot \mathrm{ha}^{-1}\right)$. In fact, the low chemical content of the litter is due to the duration and the stages of the development of the plantation. According to some authors, the chemical content of the litter is proportional to the duration of the population (Yoka et al., 2014). This statement was defended by other authors (Bernhard-Reversat et al. (1998), Bernhard-Reversat (1996), Partey et al. (2011) and Salako et al. (2001)). They also opined that it is necessary to wait for a certain time before observing an impact of Acacia on the soil properties. Previous studies on older population have shown high concentrations of mineral elements in the litter (Amandine (2011); Dommergues (1963); Bernhard-Reversat et al. (1993)). For example, Bernhard Reversat et al. (1993) was able to obtain, for a planting period of 5 years, the following quantities of elements in $\mathrm{kg} / \mathrm{ha}(\mathrm{K}: 10$; $\mathrm{Ca}: 35$ and $\mathrm{Mg}:$ 9).

Furthermore, the mineral elements that will be released by the litter produced by Acacia mangium will help improve the CEC and the soil structure by creating a flocculated state (Heller et al., 1989). In particular, calcium and magnesium will help regulate the $\mathrm{pH}$ of the soil and promote the exchange of necessary ions for plant nutrition.

\section{Conclusion}

The low water-pH values obtained under pure peanut (water-pH = 4.44) and under pure Acacia mangium (water-pH $=4.09$ ) reflect the acidity of the soil under the two treatments $(\mathrm{pH}<7)$. The peanut and Acacia mangium had no significant effect $(\mathrm{p}>0.05)$ on the evolution of the $\mathrm{pH}$ compared with the T0 control $(\mathrm{pH}<6)$ at these 12 months age of Acacia mangium. The enumerations carried out on the plot showed that there was no significant effect $(p>0.05)$ between the number of leaves produced by the peanut in pure 
cultivation and the peanut in associated cultivation. For a sustainable restoration of soil fertility and land resilience, Acacia mangium should be combined with peanut to increase their capacity. In addition, the monitoring of the biomass production of Acacia mangium at one of the longer physiological phases of the Acacia mangium cycle could reveal significant total base contents for soils for the purpose of improving the physical and chemical fertility of Grand Lahou sandy soils.

\section{References:}

1. Abe, J. (2005). Contribution à la connaissance de la morphologie et de la dynamique sédimentaire du littoral ivoirien (cas du littoral d'Abidjan) essais de modélisation en vue d'une gestion rationnelle. Thèse de doctorat d'état es-sciences naturelles, Université de CocodyAbidjan. Spécialité : Océanologie. 336 p.

2. Amandine, S. (2011). Impact de l'Acacia auriculiformis sur les propriétés des sols sableux du plateau Batéké, République Démocratique du Congo. Mémoire de Master. Université Catholique de Louvain. 98 p.

3. Bado, B.V. (2002). Rôle des légumineuses sur la fertilité des sols ferrugineux tropicaux des zones guinéenne et soudanienne du Burkina Faso. Thèse de philosophiae Doctor (ph. D.), Département des sols et de génie agroalimentaire, Faculté des sciences de l'agriculture et de l'alimentation. Université Laval, Québec, 197 p.

4. Bernhard-Reversat, F., Dianganam, D. \& Tsatsa, M. (1993). Biomasse, minéralomasse et productivité en plantation d'Acacia mangium et A. Auriculiformis au Congo. Bois et Forêts des Tropiques, 238, 4e trimestre. pp. 35-44.

5. Bernhard-Reversat, F. (1996). Nitrogen cycling in tree plantations grown on a poor sandy savanna soil in Congo. Applied soil Ecology, 4, pp.161-172.

6. Bernhard-Reversat, F. \& Schwartz, D. (1997). Evolution de la teneur en lignine et décomposition de la litière dans les sols des forêts tropicales (Congo) : comparaison de plantations exotiques et de peuplements naturels. Earth \& Planetary Sciences, 325, pp. 427-432.

7. Bernhard-Reversat F., Harmand J.M. \& Uguen, K. (1998). Les litières et la dynamique de l'azote dans divers biotopes à acacia d'Afrique occidentale et centrale. In « L’acacia au Sénégal ». pp 205-2019. ORSTOM, Paris.

8. Bonneau, M. \& Souchier, B. (1979). Pédologie : constituants et propriétes du sol. Paris, Masson, 479 p. 
9. CRAAQ (2003). Guide de référence en fertilisation. ed. Centre de référence en agriculture et agroalimentaire du Québec, Sainte-Foy. xx, 294 pp.

10. Cégep de Victoriaville et Ghislain Jutras. Guide pour l'interprétation d'une analyse de sol : Cours de « Fertilisation des sols en agriculture biologique»,6p.http://blog.acversailles.fr/formationcapa/public/MP2/I nterpretation_AnalyseSol_.pdf

11. Dommergues, Y. (1963). Les cycles biogéochimiques des éléments minéraux dans les formations tropicales. Bois et Forêts des Tropique, 87, pp. 9-25.

12. Ettien, J.B., Tschannen, A., Kone, B.R. \& Girardin, O. (2013). Assessing the potential of new yam cultivars (Dioscorea alata) in semitraditional cropping system on low fertile ferrallitisols in the savanna zone of Cote d'Ivoire. International Journal of Agronomy and Agricultural Research. Vol. 3, pp. 45-52.

13. Ettien, D. J.B., Gnahoua, J. B., Kouadio, K. K. H., Koné, B., N'Zué, B., Kouao, A. A. F., De Neve, S. \& Boeckx, P. (2016). Soil fertility in land use for sustainable food crops production in the southern Côte d'Ivoire. Agriculture and Biology Journal of North America, 7(1): 1926. DOI: 10.5251/abjna.2016.7.1.19.26

14. Floret, C. \& Serpantie, G. (1993). La jachère en Afrique de l'Ouest. In : Ch. Floret et R. Pontanier. (eds.). La jachère en Afrique tropicale. Actes de séminaire, Montpellier.

15. Georges, F. (2015). Des sols sains et durables pour des exploitations familiales résilientes. Agriculture Durable à Faibles Apports Externes (AGRIDAPE), Volume $31-\mathrm{n}^{\circ} 1,36 \mathrm{p}$.

16. Gnahoua, G. M. (2004). Contribution des légumineuses à la régénération des jachères : Intérêts et limites des arbres fixateurs d'azote en zone forestière de Côte d'Ivoire. Thèse doctorat Ingénieur, Option Agronomie, Université de Cocody - Abidjan,Côte d'Ivoire, 142 p.

17. Gnahoua, M.G., Kouassi, F Y., Angui, T. K. P., Balle, P., Olivier, R. \& Peltier, R. (2008). Effets des jachères à Acacia mangium, Acacia auriculiformis et Chromolaena odorata sur la fertilité du sol et les rendements de l'igname (Dioscorea SPP.) en zone forestière de Côte d'Ivoire. Agronomie Africaine 20 (3), pp. 291 - 301.

18. Gnahoua, J.B.G., Ettien, D.J.B., Boni N'zué, B., Ebah, C., Koné, B., Neve, S.D. \& Boeckx, P. (2016). Intensification pathway for improvement of smallholder cassava production systems in Southern côte d' ivoire. Experimental Agriculture., volume 53 (1), pp. 1-15.

19. Heller, R., Esnault, S. \& Lance, C. (1989). Physiologie végétale. MASSON, Paris.267p. 
20. Krisnawati, H., Kallio, M. \& Kanninen, M. (2011). Acacia mangium Willd.: ecology, silviculture and productivity. CIFOR, Bogor, Indonesia.

21. Moreau, R. (1993). Quelques aspects de l'évolution des caractéristiques du sol sous l'effet de la modification de la couverture forestière en zone tropicale humide. In: Ch. Floret et R.

22. Ndiaye, M. (2015). La Dégradation Des Terres Au Sénégal : La Réponse A Partir Des Arbres Fertilitaires. Agriculture Durable à Faibles Apports Externes (AGRIDAPE), Volume 31 - n¹, pp. 14-15.

23. N'goran, K. (2008). Effet des légumineuses à graines et des plantes de couverture sur la fertilité du sol et la production de l'igname en zone soudano-guinéenne et guinéenne de Côte d'Ivoire. Spécialité Agropédologie. Thèse de doctorat. Université Félix Houphouët-Boigny. $157 \mathrm{p}$.

24. Partey, S.T., Quashie-Sam, S. J., Thevathasan, N.V. \& Gordon, A.M. (2011). Decomposition and nutrient release patterns of the leaf biomass of the wild sunflower (Tithonia diversifolia): a comparative study with four leguminous agroforestry species. Agroforest. Syst., vol.81, pp.123-134.

25. Pontanier. (eds.). La jachère en Afrique tropicale, Actes de séminaire, Montpellier, 2-5 déc. 1991. Collection Colloques et Séminaires, ORSTOM, Paris : pp. $245-256$.

26. Razafindramanana, N. C., Douzet, J.-M., Barthes, B., Rabeharisoa, L. \& Albrecht, A. (2012). Évaluation des effets de systèmes de semis direct à couverture végétale pérenne (SCV) sur l'érosion hydrique et la production agricole sur les Hautes-Terres de Antsirabe (Madagascar). In «Lutte antiérosive, réhabilitation des sols tropicaux et protection contre les pluies exceptionnelles" (coordonné par E. Roose, H. Duchaufour et G. De Noni), pp. 43-52. Publié par les éditions IRD, Marseille.

27. Roose, E. (2015). Restauration de la productivité des sols tropicaux et méditerranéens Contribution à l'agroécologie. Editions Institut de Recherche pour le Développement (IRD), 542p.

28. Salako, F.K., Hauser, S., Babalola, O. \& Tian, G. (2001). Improvement of the physical fertility of a degraded Alfisol with planted and natural fallows under humid tropical conditions. Soil Use and Mangement, vol.17, pp. 41-47.

29. Schneider \& Huyghe (2015). Les légumineuses pour des systèmes agricoles et alimentaires durables. Edition Quae. 473p.

30. Todan, B. E. A., Tente, A. H. B. \& Yabi, I. (2017). Pression agrofoncière et mutations agraires sur le plateau Adja Au Sud Ouest du Benin. European Scientific Journal edition vol.13. pp.177-199. 
31. Yoka, J., Loumeto, J. J., Djego, J.G., Akouango, P. \& Epron, D. (2014). Évolution des teneurs en éléments minéraux des feuilles de niébé (Vigna unguiculata (L.) Walp.) cultivé dans la zone de Boundji en République du Congo. Journal of Applied Biosciences, 79. pp 67996807. 